\title{
8. Federalism, courts and LGBTQ policy in Canada
}

\author{
Miriam Smith
}

\subsection{INTRODUCTION}

Federalism plays an important role in LGBTQ] political mobilization and policy change. The division of powers between federal governments on the one hand and substate governments on the other hand has shaped the policy terrain for LGBTQ rights recognition. In key areas of LGBTQ policy change such as decriminalization, discrimination prohibitions, same-sex marriage, parenting laws and trans rights, the division of powers allocates key policy levers to one level of government or the other. One of the main arguments of the incipient literature on LGBTQ rights and federalism is that the allocation of jurisdiction over LGBTQ rights issues to the central government facilitates success for the LGBTQ movement, while the allocation of jurisdiction to the substate level forces the LGBTQ movement to proceed state by state or province by province to secure change (Smith 2008; 2010). This is analogous to arguments about the impact of federalism on the women's movement which stress the extent to which territorially divided state architectures impede women's representation, activism and policy influence (Haussman 2005; for a review, see Vickers 2013). However, recent comparative work sheds doubt on this clear causal relationship between centralization of power at the federal level and same-sex rights, highlighting the conditioning role of other factors such as empowered courts using a constitutional bill of rights (Johnson et al. 2011; Bernstein and Naples 2015; Johnson and Tremblay 2018), while other work highlights the divergence and complexities among provinces in Canada in the treatment of LGBTQ people (Tremblay 2016).

This chapter revisits these arguments about the causal relationships between the state architectures of federalism and LGBTQ social movements by focusing on the intersection between federalism and the role of courts in activism and policy-making. I focus on courts because of the ways in which the presence or absence of strong courts tempers and conditions the impact of federalism. As a causal or conditioning factor in facilitating or impeding the recognition of LGBTQ rights, empowered courts draw on rights instruments that are formulated and implemented through domestic bills of rights or through international or supranational covenants and courts. In the case of Canada, the focus is on the impact of the Canadian Charter of Rights and Freedoms; however, similar dynamics might be found in examining the impact of the European Court of Justice within the European Union (Helfer and Voeten 2014) or the impact of United Nations courts on subnational governments as in the case of Australia (Johnson et al. 2011, 29-30).

In exploring the relationship between federalism and litigation in shaping LGBTQ policy outcomes, I identify three dynamics on the diffusion of LGBTQ rights policies across federal and provincial jurisdictions: 1) cases in which litigation led to the diffusion of common policies across jurisdictions; 2) cases in which the litigation stalled and lack of political will led to policy stagnation; and 3) cases in which litigation outcomes did not produce policy 
consistency across the provinces because of the way in which provinces exercised their jurisdiction. For each of these dynamics, several illustrative cases are identified. These include litigation over the inclusion of sexual orientation in a provincial human rights code (Vriend $\mathrm{v}$ Alberta 1998), the rights of same-sex couples ( $M \vee H 1999)$, the reform of the federal Criminal Code, especially section 159 on anal sex (among other cases, $R \vee$ C.M. 1995), and the responsibility of schools and school boards to stop school bullying (School District No.44 (North Vancouver) v Jubran 2005). The analysis shows the importance of litigation in conditioning the effect of federalism as well as the importance of the partisan commitments of governments in facilitating policy change.

\subsection{COURTS, FEDERALISM AND LGBT RIGHTS}

Courts may provide a mechanism through which public policies diffuse across substate jurisdictions; in the area of LGBTQ rights, many scholars have emphasized the importance of a domestic bill of rights in facilitating this form of policy change (Smith 2008; Bernstein and Naples 2015; Johnson and Tremblay 2018). In broader discussions in Canadian politics, the Charter has long been viewed as a centralizing or potentially centralizing force (Cairns 1992) with the potential for creating rights-based policies that cut against provincial distinctiveness. Provincial and federal policy must conform to the Charter, with the exception of legislation that is passed using the notwithstanding clause, which permits governments to circumvent some sections of the Charter for a five-year period.

Federalism creates a complex state architecture that allocates policy areas to different jurisdictions, although these may overlap. Most systems have forms of institutionalized inter-governmentalism that provide for policy coordination between the two levels of government and across jurisdictions dealing with common issues. Traditional discussions of federalism did not pay attention to gender, racialization or other forms of internal diversity beyond, in Canada's case, binationalism (the relationship between anglophones and francophones), let alone consider how federalism would affect the political mobilization and legal rights of LGBTQ people, who in Canada, as elsewhere, were non-existent in political discourse until the late 1960s. Yet, the goals of the gay liberation, lesbian feminist, 'lesbian and gay' movement and contemporary queer and LGBT movements entail legal shifts and policy changes that engage the federal division of powers. For example, on the issue of decriminalization of homosexuality, the federal government's jurisdiction over criminal law permitted the one level of government to effect a key legal change from above while, in the case of the United States (US), activists proceeded state by state to remove sodomy prohibitions from state penal codes (Kane 2007). Similarly, in the case of same-sex marriage, federal control over who can marry facilitated policy change and removed the provinces as a potential obstacle to policy change.

While there are cases in which federalism has been argued to have important effects, there are also other cases in which these arguments about federalism do not work. One such case is that of Australia, where same-sex marriage was a question of federal jurisdiction and in which ferocious political opposition from the Australian right prevented the establishment of same-sex marriage until 2017. In the meantime, the Australian states were friendlier to LGBTQ policy change; LGBTQ political groups were able to institute de facto same-sex relationship recognition while it was the federal government that blocked the recognition of same-sex marriage. Johnson and Tremblay's (2018) work on federalism and same-sex mar- 
riage focuses on the role of political will. Indeed, the partisanship and political choices of the party in power across the federal and substate levels are clearly an important factor driving policy change. The level of political commitment to the recognition of LGBTQ rights at the various levels of government is a complicating factor in assessing the impact of institutions on policy change and the role of institutions as a structuring force in the mobilization of social movements. Institutions provide opportunity and obstacles to policy change. A federal government with sole jurisdiction in a policy area can veto change as much as facilitate it, as the Australian case makes clear.

At the same time, however, a longstanding and substantial body of scholarship points to the limited impact of courts, arguing that courts and law are a 'hollow hope', in Gerald Rosenberg's (2008) formulation, as they are often unable to depart from restrictive past precedents or to directly implement their own decisions. Linda White (2014) takes up this point in her comparison of same-sex marriage and abortion in Canada, flagging the extent to which court decisions are not fully implemented in the provinces. Comparing the aftermath of the decisions in Morgentaler and in the same-sex marriage reference case (Reference re Same-Sex Marriage 2004), White argues that in the cases of same-sex marriage and abortion, jurisdiction over policy lies with the federal level, but the implementation of the decisions and, critically, access to services is provided by the provinces. In the case of health services, while the federal Criminal Code determines what is defined as criminal and, therefore, whether or not abortion is criminal, the provinces are responsible for providing health services, including abortion. As has been well documented in the period since the Morgentaler (1988) decision, a number of provinces do not provide abortion services and, therefore, although abortion is no longer a criminal offence, women's access to it varies greatly across Canada (White 2014, 164-5). White argues that the case of same-sex marriage is similar in the sense that, while the federal government holds the jurisdiction over the determination of who can marry, the federal government does not provide the service of marriage; rather, this is provided by provinces and municipalities, although, in the years since same-sex marriage was legalized in 2005 there have not been serious problems with access to same-sex marriage.

In addition to jurisdictional divisions, governments at both levels play a role in facilitating or blocking the impact of court rulings. In some cases, provincial governments have been dragged into the recognition of LGBTQ rights through court rulings and have been forced to change provincial policies as in the case of relationship recognition and anti-discrimination protection. In other cases, there has been a legislative vacuum in the wake of Charter rulings, leaving LGBTQ rights unaddressed in policy and legislation, as in the case of Criminal Code reform. Moreover, government decisions may facilitate or impede the effect of court rulings. On the same-sex marriage file, the Liberal government decided to support same-sex marriage while, in effect, the government had the choice to resist the ruling and use the notwithstanding clause to circumvent the effects of the Charter, at least for a five-year period. Another type of government might have chosen to oppose same-sex marriage and might have committed itself to opposing the plaintiffs through a long series of court cases. In this way, the actions of governments facilitated the Charter's effects in this case as does the unitary nature of the court system in Canada compared to the judicial federalism of the US (Woehrling 2010).

In sum, litigation using a constitutional bill of rights may have a standardizing effect on LGBTQ rights, bringing policies into sync across federal and subnational jurisdictions. However, the impact of litigation is conditioned by other factors, most notably the division of jurisdiction under federalism, the lack of proactive control by courts over policy implementa- 
tion and the political choices of governments in responding to court rulings. The relationship among federalism, rights recognition and litigation can be conceptualized as entailing three dynamics: policy diffusion, policy stagnation and policy divergence.

\subsection{FEDERALISM, LITIGATION AND POLICY DIFFUSION}

Federalism often plays a role through the impact of the Charter on setting out a pan-Canadian rights framework. Even though the Charter does not directly regulate matters in provincial jurisdiction, it indirectly shapes provincial public policy by setting constitutional limits on the exercise of provincial jurisdiction. When matters have been settled by the Supreme Court, this facilitates the diffusion of common policies throughout the provinces. Policy diffusion occurred in the 1990s on the issues of prohibiting discrimination against LGB individuals (see Table 8.1) and over the period from 1998 to 2001 in the case of same-sex relationship recognition (see Table 8.2).

Two specific cases served as the linchpins of policy diffusion in these two areas: Vriend (1998) and $M \vee H$ (1999). In Vriend, an Alberta man alleged that he had been fired for being gay. He attempted to lodge a complaint with the Alberta Human Rights Commission, but the Commission declined to hear it because sexual orientation was not included as a prohibited ground of discrimination in Alberta's Individual's Rights Protection Act. Along with three gay and lesbian rights groups, he lodged a complaint at the Alberta Court of Queen's Bench claiming that his Charter rights had been violated by Alberta's refusal to include sexual orientation in its provincial human rights legislation. The Court agreed, but the Alberta government appealed to the Court of Appeal, where the majority agreed with the position of the Alberta government that the Charter did not apply to legislative omissions. In the words of the majority ruling, 'other jurisdictions [e.g. provinces] do not have to, and do not, emulate the Charter of Rights and Freedoms in their legislative responses' (Vriend v Alberta 1996). If this was to be accepted, then the Charter would not apply to provincial legislation, a very serious limitation on the Charter's application. The case was then appealed to the Supreme Court of Canada.

The Supreme Court ruled that the omission of sexual orientation from Alberta's human rights legislation was a rights violation under the Charter. The ruling recognized that the Alberta government had deliberately declined to include sexual orientation in the Individual Rights Protection Act and that, therefore, the omission could not be interpreted as neutral. Further, the omission could not be justified under section 1 of the Charter, which permits governments to violate equality rights provisions of the Charter when these are 'reasonably justified in a free and democratic society' (Vriend 1998; see the discussion in Jackman 1998, 362-6).

Through this decision, the Supreme Court brought Alberta's human rights legislation into conformity with that of other provinces and with the federal government, most of which had previously amended their legislation to include sexual orientation (see Table 8.1). In a number of provinces, the change had come about as a result of the grass roots struggles of the lesbian and gay movement, as in Ontario in 1986, or, as in the case of Quebec in 1977, as a result of the policy choice of the provincial government. In all cases, except Quebec, the Charter played an indirect role as, even at the time that section 15 came into effect in 1985, the idea that sexual orientation would be included or read into section 15 had already been discussed and anticipated (Canada Department of Justice 1986; see also Smith 1999). A train of Supreme 
Table $8.1 \quad$ Year sexual orientation added to provincial legislation by amendment or court ruling

\begin{tabular}{ccc}
\hline Jurisdiction & Year & Legislation/ruling \\
\hline Quebec & 1977 & Legislation \\
\hline Ontario & 1986 & Legislation \\
\hline Manitoba & 1987 & Legislation \\
\hline Nova Scotia & 1991 & Legislation \\
\hline New Brunswick & 1992 & Legislation \\
\hline British Columbia & 1992 & Legislation \\
\hline Saskatchewan & 1993 & Legislation \\
\hline Newfoundland and Labrador & 1995 & Ruling; by legislation in 1997 \\
\hline Canada & 1996 & Legislation \\
\hline Alberta & 1998 & Ruling \\
\hline Prince Edward Island & 1998 & Legislation
\end{tabular}

Source: Hurley 2010.

Court cases had established a clear pattern that sexual orientation was included in the equality rights provision of the Charter. Nonetheless, the Vriend case was a decisive ruling that forced provinces and territories to conform to the Charter with respect to provincial human rights legislation. Over the protests of political opponents in Alberta, the decision enforced a pan-Canadian standard of human rights protections.

While the Vriend case was a turning point for individual rights under the Charter, the case of $M \mathrm{v} H$ was the most important case for same-sex spousal rights. $\mathrm{M}$ and $\mathrm{H}$ were partners in a long-term relationship. When they separated, $\mathrm{M}$ pursued $\mathrm{H}$ for spousal support. Ontario legislation did not recognize the rights of same-sex couples for the purpose of spousal support under family law, a provincial jurisdiction. $\mathrm{M}$ filed a Charter challenge against the Ontario government, arguing that the family law legislation violated the Charter because it did not permit same-sex spouses to obtain spousal support upon breakup of a relationship. The case was appealed to the Supreme Court of Canada where $M$ won in a landmark decision. As a result, the Ontario legislation was amended to recognize same-sex couples.

Even before $M \mathrm{v} H$, provincial governments had started to change their laws to recognize same-sex spouses. The case was on the horizon and the recognition of sexual orientation as a prohibited ground of discrimination by the Supreme Court in Egan and Vriend provided grounds for expecting that provincial laws would need to be changed. It is clear that $M \mathrm{v} H$ had a centralizing impact on relationship recognition in the provinces. In the late 1990s, prior to the final ruling of 1999, provinces and territories diverged in the recognition of same-sex spousal benefits; however, a few years after $M \mathrm{v} H$, all provinces and territories had changed their policies to conform with it. Table 8.2 shows the points at which legislation was amended in the provinces to recognize same-sex relationships and the timing shows the clear impact of the pending case and the decision in $M \mathrm{v} H$. Therefore, although the provinces have control over the legal recognition of common law spousal relationships and, in the case of Quebec, over the analogous union de fait relationships under the civil code, the effect of the Supreme Court decision was to bring about policy conformity. Nonetheless, the litigation process through which the uniformity was created reflected the divided jurisdictions of federalism.

In the cases of discrimination (Vriend) and same-sex benefits $(M \vee H)$, the Supreme Court exerted a centralizing effect in diffusing a common template of rights protections across the 
Table $8.2 \quad$ Same-sex couples recognized in family law

\begin{tabular}{cl}
\hline Jurisdiction & Year \\
\hline Ontario & 1999 \\
\hline Canada & 2000 \\
\hline British Columbia & 2000 \\
\hline Nova Scotia & 2000 \\
\hline Newfoundland and Labrador & 2000 \\
\hline Manitoba & 2001 \\
\hline Saskatchewan & 2001 \\
\hline Alberta & 2002 \\
\hline Prince Edward Island & 2002 \\
\hline Quebec & 1998 \\
\hline New Brunswick & 2001 \\
\hline
\end{tabular}

Source: Hurley 2010.

provinces and territories through its decisions. Policy diffusion across subnational units has often been considered in terms of policy learning or policy innovation. However, in the case of LGB rights, important areas of policy were changed as a result of Supreme Court decisions, which then diffused across the country. The process of litigation sparked anticipatory policy change in advance of final court rulings and helped to cement the place of LGB rights on the policy agenda of the provinces. The effect of the rulings was to enforce a conformity in LGB rights across Canada in these policy areas. Diffusion resulted from litigation. Policies were adopted in provinces in which the provincial government disagreed with them, as in the case of Alberta with Vriend or the case of Ontario with $M \mathrm{v} H$, because of the effect of court action. In this way, litigation in the Supreme Court is a key mechanism in policy diffusion in these policy areas.

\subsection{LITIGATION AND POLICY STAGNATION}

While Vriend and $M \mathrm{v} H$ provide examples of the standardization of LGBTQ rights throughout Canada as a result of Charter litigation, in other policy areas, litigation may fail to have pan-Canadian effects because cases do not reach the Supreme Court of Canada. Despite positive decisions for LGBTQ rights in lower courts, the lack of a Supreme Court decision tempers the effect of litigation. In addition, the failure of litigation to produce a decisive result at the highest level may be compounded by federal and/or provincial inaction on the file. Federal and provincial governments may feel free to ignore the litigation or to take steps that undermine LGBTQ rights, depending on their partisan commitments.

Criminal law provides an example. Criminal law is a federal jurisdiction which, in 1969, facilitated the partial decriminalization of homosexuality. In 1969, the Liberal-majority government was able to pass legislation partially decriminalizing homosexuality without the need for provincial input, let alone consent. In contrast, in the US, the campaign to reform state sodomy laws took 30 years. While campaigns to reform state penal codes did have some success in decriminalizing sodomy, a few states remained recalcitrant and were brought into conformity through the Supreme Court decision in Lawrence (2003), as in the pattern described in the previous section (Pierceson 2005). The Australian case shows a similar pattern. As the 
criminal law is assigned to the states in Australian federalism, state-by-state reform campaigns were effective in changing the law; however, Tasmania, a hold-out, was forced to act finally through court action, with the encouragement of the Australian government (Johnson et al. 2011). Therefore, in comparative perspective, substate jurisdiction over criminal law has slowed the recognition of the forms of LGBTQ rights that require criminal law amendment.

At the same time, however, as scholars such as Kinsman (2013) and Hooper (2014) have pointed out, the Canadian legal change of 1969 was a partial decriminalization. Successive federal governments have failed to amend the Criminal Code to equalize the provisions on the age of consent or to eliminate provisions on gross indecency and the bawdy house that have been used to police queer communities. Reforms of the mid-1980s removed the term 'gross indecency' and replaced it with section 159 on anal sex. This provision sets up a different age of consent for anal sex, with the age of consent set at 14 for heterosexual intercourse and the age of consent set at 18 for anal sex, other than that between a husband and wife.

Section 159 has been repeatedly challenged under the Charter. In Regina v Carmen M. (1995) in the Ontario Court of Appeal, the court ruled that section 159 violated the Charter. In that case, a heterosexual couple had anal sex when the woman was under age and they were unmarried. The man was prosecuted under section 159. All three justices agreed that the provision violated the Charter, with two arguing that it did so on the grounds of age, while the third, future Supreme Court Justice Rosalie Abella, ruled that section 159 violated the Charter on the grounds of sexual orientation $(R \vee C M 1995)$. Abella highlighted the fact that anal sex had been singled out for different treatment under the law and argued that the anal sex provision of the Criminal Code specifically affected gay men, given that anal sex was 'a basic form of sexual expression for them', in her words.

Following $R$ v $C M$, a number of other courts ruled similarly. In 1995, the federal court ruled that section 159 was unconstitutional in the case of Halm v Canada. The court ruled that section 159 discriminated on the basis of sexual orientation and on the basis of age as the age of consent was otherwise 14 at the time. In the 1998 case of $R$. c. Roy, and in the Ontario case of $R$ v $S(A)$ (2002), the same conclusion was reached. In 2002, the Alberta Court of Queen's Bench ruled that section 159 violated section 15 of the Charter on the grounds of age, marital status and sexual orientation ( $R$ v Roth 2002) in a case involving a man who had anal sex with a woman in the presence of another man. In $R$ v Blake (2003) in British Columbia (BC), the court accepted that section 159 was unconstitutional in light of previous precedents while, in Ontario in 2001, a person was charged under section 159; although the charges were withdrawn, he brought a civil case against the Attorney General arguing that section 159 should have been repealed. Although his case failed, this demonstrates the frustration of dealing with a section that has been declared unconstitutional by the courts and yet had not been repealed. The same decision was confirmed in the Nova Scotia Court of Appeal in 2006 ( $R \vee F 2006$ NSCA 42), bringing to six the total number of provinces whose courts had struck down section 159 .

This train of litigation had no effect on federal government policy, however. During the 1990s, the Liberal government was slow to move on the recognition of lesbian and gay rights, as they were then termed. The government dragged its feet on changing federal human rights legislation to include sexual orientation, even though a train of court decisions had indicated that sexual orientation was included de facto in light of the Charter's rights guarantees. Even when the federal Liberals decided to push forward with same-sex marriage in 2005, there was no discussion of section 159. While the federal government failed to amend the Criminal Code, it also declined to appeal the lower court decisions, thus leaving the authorities free to 


\section{Handbook on gender, diversity and federalism}

continue to charge individuals under the section and putting the burden on plaintiffs to challenge the state's actions in court, despite the multiple rulings on the law's unconstitutionality.

During the 2000s, the Conservative government of Stephen Harper took steps to deepen the inequality in the age of consent for anal sex by amending the Criminal Code to raise the age of consent for heterosexual intercourse from 14 to 16 . While this reduced the disparity between the two ages of consent from four years to two, it also demonstrated the government's determination to continue to uphold a provision that had been repeatedly struck down by the lower courts as a Charter violation. The review of the age of consent forced the government to explicitly confront the unconstitutional difference in the age of consent and to explicitly decline to redress the inequality. A number of queer groups appeared before the federal parliament to point out the problems with this inequality and to advocate for a change in government policy (Dauda 2010; Harper 2008). These efforts were rebuffed and the age of consent remained the same. Thus, without paying the political cost of declaring the section of the Criminal Code to be operating notwithstanding the Charter, an act that would have had to have been renewed by the federal Parliament every five years, the government quietly evaded its Charter responsibilities.

With the election of a Liberal government in 2016, the partisan complexion changed and government promised to undertake a revision of the Criminal Code. However, two years after the government's election, the anal sex provision has not yet been changed despite the fact that more than 20 years has passed since the first 1995 lower court decision striking it down. In 2018, the government tabled legislation to remove the anal sex provision; however, this proposal was condemned by historians of LGBTQ rights who pointed out that the government had still declined to remove legacy provisions of the statute such as the bawdy house laws (Gentile et al. 2018).

In sum, positive decisions for LGBTQ rights under the Charter do not guarantee policy change, especially when these decisions are not appealed to the Supreme Court. A partisan commitment to undermining LGBTQ rights such as that displayed by the Harper government or a sense of wanting to avoid political controversy, which seems to factor into Liberal government decision making, also undercuts the impact of a consistent pattern of lower court decisions over a 20-year period. Even when LGBTQ issues are assigned to federal jurisdiction, there is no guarantee of federal government action to recognize them, even when they are subject to Charter-based litigation.

\subsection{LITIGATION AND POLICY DIVERGENCE}

A third dynamic in the intersection of litigation and federalism concerns inter-provincial policy divergence in areas that fall under provincial jurisdiction. In this dynamic, provincial control over particular jurisdictions permits substantial policy variation, even working with a common Charter framework that recognizes LGBTQ rights. Education policy is an important area of provincial jurisdiction and one that has been highlighted in LGBTQ policy debates in recent years. Debates have focused on the right of LGBTQ students to be free from bullying, the adoption of curriculum that reflects the identities of same-sex-headed families and queer and trans students, and gay-straight alliances (among other issues).

Many of the policies affecting LGBTQ students in school are the responsibilities of school boards, which operate under provincial jurisdiction. Some cases have been brought against 
school boards by contesting students and parents and these cases have shaped local practices and, in some cases, may have indirectly shaped amendments to provincial education legislation (for an overview, see Anderson 2014). With regard to anti-gay bullying, the most important case is that of BC high school student Azmi Jubran. Jubran brought a case in the BC Human Rights Tribunal against a BC school board after he was bullied for years in high school by students who called him homophobic names. While Jubran was not gay, he claimed discrimination on the grounds of sexual orientation. The Human Rights Tribunal found in his favor (School District No.44 (North Vancouver) v Jubran 2005) and the school board appealed to the Supreme Court of BC, which overturned the Tribunal's decision. While that court ruled that Jubran could not claim discrimination based on sexual orientation when he was not gay, this decision was overturned by the BC Court of Appeal. In addition, the Court of Appeal ruled that the school board was responsible for the behavior of students in the school, an important finding for the rights of LGBTQ students. As Anderson points out, 'having only an antigay bullying policy might be insufficient to provide queer students with a safe learning environment; additional measures, such as queer supportive policies and an inclusive curriculum, are likely needed' (Anderson 2014, 220). In this way, anti-bullying policies, curriculum change and policies such as gay-straight alliances are interlinked in the discussion of policy change.

The implications of Jubran were that Canadian school boards can be held responsible for the behavior of students when it comes to homophobic bullying. The Egale 2011 report on education found that anti-homophobia policies in schools reduced harassment for white LGBTQ students (Taylor and Peter 2011, 18), although, overall, the study found a tremendous level of harassment against LGBTQ students in Canadian schools, especially against racialized students. Fetner et al.'s study of gay-straight alliances in Canada and the US emphasized that gay-straight alliances have mixed effects, depending on the ways in which these are integrated into schools and, in particular, whether the school itself is supportive of the club as an institution $(2012,203)$. Therefore, school board policies have the potential to have a direct effect on the wellbeing of young members of queer communities. Yet, despite the overwhelming evidence of the harm to LGBTQ youth from social exclusion and bullying within schools, provinces diverge in the extent to which they have enacted policies against bullying, directives on curriculum change or requirements that schools and school boards recognize and facilitate gay-straight alliances.

Ontario and Quebec have led the way in legislative change to recognize the importance of establishing a safe atmosphere for LGBTQ students. Quebec's Policy Against Homophobia and Transphobia (Quebec Ministry of Justice 2017) is the most extensive in Canada and requires a systematic review of all areas of public policy in the provinces to counter homophobia and transphobia in social services, education, health, the administration of justice and other areas of provincial jurisdiction. In relation to schools, Quebec amended its Education Act in 2012 to prohibit bullying in schools. This multitier policy entails provincial regulation as well as requiring school policies that not only prohibit bullying but set out specific steps that schools must take to prevent bullying, address school violence, involve parents, staff and students, respond to complaints and support bullied students. The legislation specifically mentions bullying on the grounds of homophobia, sexual orientation and sexual identity.

Ontario's 2012 amendments to the Education Act enacted similar anti-bullying provisions, specifically mentioning bullying on the basis of sexual orientation, gender identity and gender expression. In addition, Ontario requires that schools recognize gay-straight alliances and permit them to operate within the school (Kitchen and Bellini 2013). Alberta has recognized 
gay-straight alliances within the schools and required that they operate in schools where students wish, without informing parents, despite a court challenge (Alberta Ministry of Education 2017; Krugel 2018). Manitoba followed Ontario in passing comprehensive anti-bullying legislation in 2013 (Manitoba 2013). However, other provinces have not amended education legislation to advance these policy areas, despite the Jubran case.

In these cases, we see the role of partisanship at the provincial level. With the exception of Quebec, where anti-bullying legislation and the provincial anti-homophobia policies have been supported by Parti Québécois and Liberal governments, anti-bullying legislation was passed by provincial New Democratic Party governments (Manitoba, Alberta) or by left-of-center Liberal provincial governments (Ontario). Other provinces have so far declined to amend their provincial education legislation, despite legal challenges to school board practice such as Jubran. The decentralized organization of education in the provinces, the role of school boards and the lack of a Supreme Court decision that would require government action to prevent violence and bullying against LGBTQ students in schools have prevented the policy diffusion that we see in other policy areas.

\subsection{CONCLUSIONS}

LGBTQ issues are shaped by political institutional factors, just like any other area of public policy. Yet, traditionally, the study of federalism, whether Canadian or comparative, has ignored LGBTQ topics. In turn, scholarly debates on LGBTQ rights have often ignored formal legal-institutional factors such as federalism, focusing instead on the normative dimension of rights recognition. In contrast, in recent years, there has been a substantial growth in scholarship that explores the empirical side of LGBTQ policy change, seeking to identify the factors that facilitate or impede rights recognition. Comparative, institutional and sociological work in a range of national, supranational and international settings has drawn attention to political institutions as a shaping context for political action (e.g. Winter et al. 2018; Kollman 2016). The emerging scholarship on gender and federalism (Vickers 2013) has opened a space for discussing the specific dynamics involved in gender-based policy change in federal systems.

Traditional views on the relationship between social movement mobilization, policy change and federalism identified key dynamics such as policy innovation in subnational units, the spread of policy change from one jurisdiction to another and the centralization of policy change, depending on the jurisdictional division between the two levels of government. In this chapter I have conceptualized these three dynamics as policy diffusion, policy stagnation and policy divergence and provided case studies of each. Because of the important role of courts in relation to LGBTQ issues, the chapter explored the relationship between federalism and courts in shaping the process of change and the nature of policy outcomes.

In the case of policy diffusion or what might be seen as the centralization and standardization of policy through litigation, the determinative cases reached the Supreme Court of Canada. The anticipation or effect of Supreme Court rulings was to diffuse the same policies across the provinces, even when the policy areas were assigned to provincial jurisdiction. In the case of Vriend, the policy area was discrimination under provincial human rights legislation. In the case of $M \mathrm{v} H$, the policy area was the spousal rights of same-sex couples upon breakup of a common law relationship, a provincial jurisdiction. In both cases, provinces had already changed their laws prior to the Supreme Court decision or they changed their laws 
in the wake of it. In contrast, in the case of the second dynamic, policy stagnation, the issue (criminal law) falls solely in federal jurisdiction, which should have facilitated rapid policy change; however, the litigation over the constitutionality of federal criminal provisions did not reach the Supreme Court of Canada (section 159). Therefore, the Criminal Code was not changed, and a small number of charges have continued to be lodged over the years. In the third dynamic, that of policy divergence, a policy issue (education) that is assigned to provincial jurisdiction was not litigated at the Supreme Court. Again, as in the second dynamic, policy change has not diffused across the provinces. Instead, provinces diverge in the extent to which their laws aim to protect LGBTQ students from bullying in school, incorporate LGBTQ materials into the curriculum and facilitate gay-straight alliances in schools.

In sum, it is clear that the extent of litigation and the division of powers in specific areas that affect LGBTQ rights produces a set of complex dynamics. In addition, several of the examples in this chapter highlight the impact of the partisan choices of governments. In particular, the shift in the federal Liberal Party from reluctance toward LGBTQ rights in the 1990s to the full embrace of same-sex marriage in the mid-2000s was critically important to facilitating the impact of litigation on federal policy decisions. There are institutional means through which federal governments can resist court decisions; however, these options were not taken by the Liberal government over the issue of same-sex marriage or by the Conservative government of Stephen Harper subsequently. Yet, the case of criminal law suggests the role of deliberate political choice at the federal level in impeding policy change. While section 159 (anal sex) of the Criminal Code was struck down by an Ontario court in 1995, as of 2018 the Criminal Code has not yet been amended to reflect the decision of that court or of six other lower courts on the same question. Therefore, as Johnson and Tremblay (2018) point out, political will plays an important role in facilitating the impact of structural institutional factors.

\section{NOTES}

1. I use the term LGBTQ to denote lesbian, gay, bisexual, trans and queer people. I sometimes use the abbreviation LGB to refer to lesbian, gay and bisexual people, as in cases in which trans interests are not directly engaged and in an historical period in which 'queer' was not a common umbrella term, as it is today.

2. This research was supported by a Partnership Grant from the Social Sciences and Humanities Research Council of Canada entitled 'Savoirs sur l'inclusion et l'exclusion des personnes LGBTQ (SAVIE-LGBTQ)'. Principal investigator: Line Chamberland, Université du Québec à Montréal, 2016-22. Hayden Sahid provided research assistance. This support is gratefully acknowledged.

\section{REFERENCES}

\section{Cases, Bills and Statutes}

Halm v Canada (Minister of Employment and Immigration) [1995] 2 FC 331

Lawrence v Texas 539 U.S. 558 (2003)

$M$ v $H$ [1999] 2 SCR 3

Manitoba (2013) Ministry of Education. Bill 18: The Public Schools Amendment Act (Safe and Inclusive Schools https://web2.gov.mb.ca/bills/40-2/b018e.php

Quebec. Education Act. \$75.1 (amended 2012) http://legisquebec.gouv.qc.ca/en/ShowDoc/cs/I-13.3 


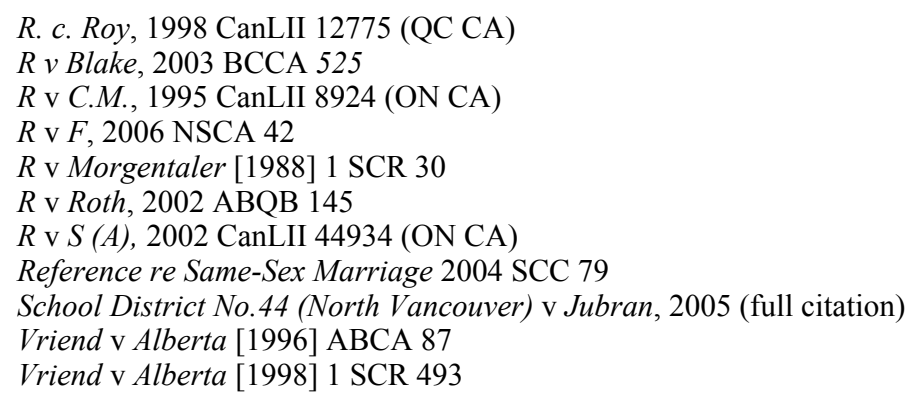

\section{Other Sources}

Alberta Ministry of Education (2017), 'What Is a GSA?', accessed June 17, 2017 at https://education .alberta.ca/gay-straight-alliances/what-is-a-gsa/

Anderson, J. (2014), 'Providing a Safe Learning Environment for Queer Students in Canadian Schools: A Legal Analysis of Homophobic Bullying', Journal of LGBT Youth, 11 (3), 212-43.

Bernstein, M. and N.A. Naples (2015), 'Altared States: Legal Structuring and Relationship Recognition in the United States, Canada, and Australia', American Sociological Review, 80 (6), 1226-49.

Cairns, A.C. (1992), Charter versus Federalism: The Dilemmas of Constitutional Reform, Montreal: McGill-Queen's University Press.

Canada Department of Justice (1986), Toward Equality: The Response to the Report of the Parliamentary Committee on Equality Rights, Ottawa: Communications and Public Affairs.

Dauda, C.L. (2010), 'Childhood, Age of Consent and Moral Regulation in Canada and the UK', Contemporary Politics, 16 (3), 227-47.

Fetner, T., A. Elafros, S. Bortolin and C. Drechsler (2012), 'Safe Spaces: Gay-Straight Alliances in High Schools', Canadian Review of Sociology, 49 (2), 188-208.

Gentile, P., T. Hooper, G. Kinsman and S. Maynard (2018), Another Flawed Bill: Gay and Lesbian Historians on C-75, June 12, accessed June 16, 2018 at http://radicalnoise.ca/2018/06/12/another -flawed-bill-gay-and-lesbian-historians-on-bill-75/

Harper, L. (2008), 'Youth Groups Tell Senate to Keep Consent Age at 14', Daily Xtra (Toronto), February 21, accessed June 17, 2018 at www.dailyxtra.com/youth-groups-tell-sente-to-keep-consent -age-at-14-38608

Haussman, M. (2005), Abortion Politics in North America, Boulder: Lynne Rienner.

Helfer, L.R. and E. Voeten (2014), 'International Courts as Agents of Legal Change: Evidence from LGBT Rights in Europe', International Organization, 68 (1), 77-110.

Hooper, T. (2014), "More Than Two Is a Crowd": Mononormativity and Gross Indecency in the Criminal Code, 1981-82', Journal of Canadian Studies, 48 (1), 53-81.

Hurley, M.C. (2010), Sexual Orientation and Legal Rights: A Chronological Overview, Ottawa: Parliamentary Information and Research Service, Library of Parliament.

Jackman M. (1998), “'Giving Real Effect to Equality”: Eldridge v British Columbia (Attorney General) and Vriend v Alberta', Review of Constitutional Studies, 4 (2), 352-70.

Johnson, C. and M. Tremblay (2018), 'Comparing Same-Sex Marriage in Australia and Canada: Institutions and Political Will', Government and Opposition, 53 (1), 131-58.

Johnson, C., S. Maddison and E. Partridge (2011), 'Australia: Parties, Federalism and Rights Agendas', in M. Tremblay, D. Paternotte and C. Johnson (eds), The Lesbian and Gay Movement and the State: Comparative Insights into a Transformed Relationship, Farnham: Ashgate, 27-42.

Kane, M.D. (2007), 'Timing Matters: Shifts in the Causal Determinations of Sodomy Law Decriminalization, 1961-1998', Social Problems, 54 (2), 211-39.

Kinsman, G. (2013), 'Wolfenden in Canada: Within and Beyond Official Discourse in Law Reform Struggles', in C. Lennox and M. Waites (eds), Human Rights, Sexual Orientation and Gender Identity in the Commonwealth: Struggles for Decriminalisation and Change, London: School of Advanced Study, University of London, 183-205. 
Kitchen, J. and C. Bellini (2013), 'Making Schools Safe and Inclusive: Gay-Straight Alliances and School Climate in Ontario', Canadian Journal of Educational Administration and Policy 146, accessed July 1, 2018 at https://journalhosting.ucalgary.ca/index.php/cjeap/article/view/42853

Kollman, K. (2016), The Same-Sex Unions Revolution in Western Democracies: International Norms and Domestic Policy Change, Manchester: Manchester University Press.

Krugel, L. (2018), 'Closely Watched Alberta Gay-Straight Alliance Challenge Fills Courtroom', June 20, accessed July 1, 2018 at www.cbc.ca/news/canada/calgary/alberta-gay-straight-alliance-gsa-court -challenge-1.4714137

Pierceson, J. (2005), Courts Liberalism and Rights: Gay Law and Politics in the United States and Canada, Philadelphia: Temple University Press.

Quebec Ministry of Justice (2017), Government Action Plan Against Homophobia and Transphobia 2017-2022, Quebec: Ministry of Justice, accessed June 28, 2018 at www.justice.gouv.qc.ca/ fileadmin/user_upload/contenu/documents/En__Anglais_/centredoc/publications/ministere/plans -actions/plan_action_homo_EN.pdf

Rosenberg, G. (2008), The Hollow Hope: Can Courts Bring about Social Change?, 2nd ed., Chicago: University of Chicago Press.

Smith, M. (1999), Lesbian and Gay Rights in Canada: Social Movements and Equality-Seeking, 1971-1995, Toronto: University of Toronto Press.

Smith, M. (2008), Political Institutions and Lesbian and Gay Rights in the United States and Canada, New York: Routledge.

Smith, M. (2010), 'Federalism and LGBT Rights in the US and Canada: A Comparative Policy Analysis', in M. Haussman, M. Sawer and J. Vickers (eds), Federalism, Feminism and Multilevel Governance, Vermont: Ashgate, 97-110.

Taylor, C. and T. Peter (2011), Every Class in Every School: The First National Climate Survey on Homophobia, Biphobia, and Transphobia in Canadian Schools, final report, Toronto: Egale Human Rights Trust.

Tremblay, M. (2016), 'Citoyenneté substantielle des lesbiennes et des gais et politiques publiques au Canada: réflexions autour de la notion d'"homofédéralisme"', Zeitschrift Für Kanada-Studien, 36 (1), 9-27.

Vickers, J. (2013), 'Is Federalism Gendered? Incorporating Gender into Studies of Federalism', Publius: Journal of Federalism, 43 (1), 1-23.

White, L.A. (2014), 'Federalism and Equality Rights Implementation in Canada', Publius: Journal of Federalism, 44 (1), 157-82.

Winter, B., M. Forest and R. Senac (eds) (2018), Global Perspectives on Same-Sex Marriage: A Neo-Institutional Approach, London: Palgrave Macmillan.

Woehrling, J. (2010), 'Federalism and the Protection of Rights and Freedoms: Affinities and Antagonism', in Requejo Ferran and Miquel Caminal (eds), Political Liberalism and Plurinational Democracies, New York: Routledge, 139-56. 